\title{
Induction characteristics and optimization of production conditions of Xylanase by selected fungal species on lignocellulosic substrates
}

\author{
Mohammed Inuwa JA'AFARU ${ }^{1 *}$ and Abiodun Anthony ONILUDE ${ }^{2}$ \\ ${ }^{I}$ Department of Microbiology, Modibbo Adama University of Technology, \\ PMB 2076, Yola. Nigeria. \\ ${ }^{2}$ Microbial Physiology and Biotechnology Research Group, Department of Botany and Microbiology, \\ University of Ibadan, Nigeria. \\ Corresponding author; E-mail: mijaafaru@yahoo.com; Phone No.: +2340805 4031748
}

\begin{abstract}
Five xylanolytic fungi were isolated from saw dust samples collected from a saw mill dump in Ibadan, Nigeria. The effect of lignocellulosic substrates on the production of xylanases was studied in shake flasks. Trichoderma sp. Fd4 produced high yield of the enzyme when grown in $2 \%$ wheat bran. Similarly, xylan, lactose and maltose, used as carbon sources induced the production of high levels of xylanase. Trichoderma viride $\mathrm{Fd} 18$ produced $10.4 \mathrm{U} / \mathrm{ml}$ of xylanase using $\mathrm{NH}_{4} \mathrm{Cl}$ as nitrogen source, while $\mathrm{NH}_{4} \mathrm{NO}_{3}$ repressed enzyme production by Aspergillus ustus $\mathrm{Fb} 2$. The fungal isolates produced good amount of xylanase at $30-40{ }^{\circ} \mathrm{C}, \mathrm{pH}$ 4.5-6.0, 7 days of incubation, initial spore size of $10^{6}$ and in presence of $\mathrm{NaCl}$ and $\mathrm{KCl}$ in the basal medium. (C) 2014 International Formulae Group. All rights reserved.
\end{abstract}

Keywords: Xylanase, fungi, lignocellulosic waste, submerged fermentation, optimization.

\section{INTRODUCTION}

Hemicellulolytic enzymes have aroused great interest due to their biotechnological potential in many industrial processes. Plant hemicellulosic biomass, the second most abundant and renewable organic compound in nature, can be converted to reducing sugars by means of xylanolytic enzymes produced by microorganisms. These sugars are eventually converted to useful products by other microorganisms. The major component of hemicellulose is xylan, a noncrystalline complex polysaccharide consisting of a backbone of $\beta-\mathrm{D}-1,4-$ linked xylopyranoside units substituted with acetyl, glucuronosyl and arabinosyl side chains ( $\mathrm{La}$
Grange et al., 2001). A complete and efficient enzymatic hydrolysis of xylan depends mainly on two types of enzymes: endoxylanases (EC 3.2.1.8) which hydrolyse the xylanopyranose of the central chain and $\beta$-xylosidases (EC 3.2.1.37) which hydrolyse xylobiose and other xylooligosaccharides. Lignocellulosic waste forms a large proportion of solid waste in our cities, thus, constituting an environmental problem. Studies have shown that conventional waste treatment strategies have failed to ameliorate this problem. The use of microbial enzymes in lignocellulosic waste treatment has been shown to be an alternative that is efficient and cost-effective. Therefore, considering the industrial potentials of xylanases and their potential use in 
lignocellulolytic waste treatment, it becomes imperative to obtain new enzymes and enzyme-producing microbial strains that produce highly active xylanases at low cost. Microbial enzymes are the preferred catalyst for hydrolysis due to their high specificity, mild reaction conditions, negligible substrate loss and side product generation (Kulkarni et al., 1999).

Filamentous fungi are particularly useful producers of xylanases from the industrial point of view, due to the high production level and extra cellular secretion of enzymes, as well as elative ease of cultivation. In general, xylanase activity levels from fungal cultures are typically much higher than those from yeasts or bacteria (Tallapragada and Venkatesh, 2011; Irfan and Syed, 2012). The purpose of this research was to evaluate xylanase production by 5 fungal isolates grown in submerged fermentation using some natural lignocellulosics and to standardize some enzyme production parameters.

\section{MATERIALS AND METHODS}

\section{Isolation and identification of fungi}

The fungi were isolated from saw dust samples collected from the Bodija saw mill dump in Ibadan, Nigeria. The isolated fungi were identified after growth on PDA medium by observing its macroscopic (colour, texture, appearance and diameter of colonies) and microscopic (microstructures) characteristics according to Barnett (1960), and Domsch et al. (1980). The pure cultures were then transferred to PDA slants and maintained by sub-culturing every four weeks.

Xylanase production by fungal isolates in submerged fermentation

One millilitre of fungal spore suspension ( 10 $0^{7}$ spores $\left./ \mathrm{ml}\right)$ from a 6-dayold PDA slants were inoculated into the modified medium of Mandels and Weber
(1969) containing $1 \%(\mathrm{w} / \mathrm{v})$ oatspelt xylan (20 $\mathrm{ml}$ in $50 \mathrm{ml}$ flasks) and incubated at $30{ }^{\circ} \mathrm{C}$ with continous agitation (180 rev/min) for 6 days. The content of each flask was filtered through Whatman filter paper No.1 and the supernatant solution was used as crude enzyme preparation.

\section{Xylanase production on various lignocellulosics}

Fungal isolates were screened for their ability to utilize various natural lignocellulosics (wheat bran, sugarcane bagasse and saw dust) to produce xylanase in submerged cultivation at $30{ }^{\circ} \mathrm{C}$ for 6 days as described by Franco et al. (2004).

Xylanase production by solid state fermentation

Lignocellulosic substrates (wheat bran, sugarcane bagasse and saw dust) served as carbon source as well as matrix for SSF. Five gram $(5 \mathrm{~g})$ of the solid substrate was moistened with $5 \mathrm{ml}$ of modified medium of Mandels and Weber (1969) in $250 \mathrm{ml}$ conical flasks. The flasks were autoclaved at $121{ }^{\circ} \mathrm{C}$ for $20 \mathrm{~min}$, after which they were each inoculated with 1 $\mathrm{ml}$ of spore suspension $\left(\sim 10^{7}\right.$ spores $\left.\mathrm{ml}^{-1}\right)$ and incubated for 6 days at $30{ }^{\circ} \mathrm{C}$. Enzyme was harvested by shaking thoroughly with $100 \mathrm{ml}$ $0.05 \mathrm{M}$ sodium citrate buffer $(\mathrm{pH} 5.0)$. The contents of the flasks were filtered using Whatman No.1 filter paper and the clear supernatant was assayed for enzyme activities (Jeya et al., 2005).

\section{Optimization of production conditions}

The optimization of fermentation parameters was done by evaluating the effect of an individual parameter and to incorporate it at standardized level before standardizing the next parameter. Process parameters optimized included $\mathrm{pH}(3.0-8.0)$ adjusted with $0.1 \mathrm{M}$ sodium citrate and $0.1 \mathrm{M}$ sodium phosphate buffers, incubation temperature $\left(30{ }^{\circ} \mathrm{C}-55\right.$ ${ }^{\circ} \mathrm{C}$ ), and additional nutrients: $\mathrm{NH}_{4} \mathrm{Cl}$, 
$\left(\mathrm{NH}_{4}\right)_{2} \mathrm{SO}_{4}, \quad \mathrm{NaNO}_{3}, \quad \mathrm{NH}_{4} \mathrm{H}_{2} \mathrm{PO}_{4}, \quad$ Urea, $\mathrm{KNO}_{3},\left(\mathrm{NH}_{2}\right)_{2} \mathrm{HPO}_{4}, \mathrm{NH}_{4} \mathrm{NO}_{3}$, and Peptone each at concentration of $0.1 \% \mathrm{w} / \mathrm{v}$ as nitrogen sources, and maltose, lactose, mannitol, sorbitol, and glycerol each at $0.5-2.5 \%$ concentration as additional carbon sources. Effect of mineral salts $\left(\mathrm{CaCl}_{2}, \mathrm{CoSO}_{4}, \mathrm{FeSO}_{4}\right.$, $\mathrm{MgSO}_{4}$, and $\mathrm{ZnCl}_{2}$ ) and incubation period were also optimized.

\section{Enzyme assay}

Xylanase activity was assayed according to the method of Bailey et al. (1992) using 1\% (w/v) oat spelt xylan (Sigma Chemical Co., St. Louis, Mo.) as substrate and incubation of the entire mixture carried out at $50{ }^{\circ} \mathrm{C}$. Xylose (Sigma Chemical Co., St. Louis, Mo.) was used as standard. One unit of xylanase was defined as the amount of enzyme required to release $1 \mu \mathrm{mol}$ of xylose/minute.

\section{RESULTS}

A high level of xylanase was produced when xylan, lactose and maltose were used as carbon sources (Table 1). The maximum level of xylanase activity $\left(10.8 \mathrm{Uml}^{-1}\right)$ was produced by Aspergillus ustus $\mathrm{Fb} 2$ using lactose (2\%). Trichoderma sp Fd7 produced $9.62 \mathrm{Uml}^{-1}$ xylanase using $2 \%$ maltose; whereas Trichoderma sp Fd4, A. ustus Fd12 and $T$. viride Fd18 produced 9.7, 9.32 and $9.56 \mathrm{Uml}^{-1}$ xylanase, respectively, using $2 \%$ oat-spelt xylan as carbon source.

The agricultural substrates, wheat bran and sugarcane bagasse, were better in synthesizing xylanase than saw dust. Trichoderma sp. Fd4 and Trichoderma viride Fd18 generated 17.2 $\mathrm{Uml}^{-1}$ and $17.0 \mathrm{Uml}^{-1}$ of xylanase in $2 \%$ wheat bran respectively, showing no difference $(p>0.05)$ in the enzyme activity. A. ustus Fb2 (15.2 $\mathrm{Uml}^{-1}$, 1\%), Trichoderma sp Fd7 (14.1 $\left.\mathrm{Uml}^{-1}, 2 \%\right)$ and A. ustus Fb12 (14.1 $\left.\mathrm{U} \mathrm{ml}^{-1}, 3 \%\right)$ produced their highest values of xylanase by utilizing sugarcane bagasse as carbon source (Table 2).

Result of experiments to compare the production of xylanase using solid state fermentation (SSF) and submerged fermentation $(\mathrm{SmF})$ is shown in Table 3 . Compared to $\mathrm{SmF}$, the yield of xylanase in SSF was significantly lower at $\mathrm{p} \leq 0.05$. Trichoderma viride $\mathrm{Fd} 18$ and A. ustus $\mathrm{Fb} 2$ generated $17.8 \mathrm{Uml}^{-1}$ and $13.2 \mathrm{Uml}^{-1}$ xylanase activities in $\mathrm{SmF}$, and $16.3 \mathrm{Uml}^{-1}$ and 11.8 $\mathrm{Uml}^{-1}$ in SSF respectively using wheat bran as substrate. When saw dust was used as substrate, A. ustus $\mathrm{Fb} 2$ produced $7.9 \mathrm{Uml}^{-1}$ of xylanase in SSF compared to $5.0 \mathrm{Uml}^{-1}$ produced in SmF. Wheat bran was the most suitable substrate for the generation of xylanase activities in both SSF and SmF.

Trichoderma viride Fd18 produced significantly $(\mathrm{p} \leq 0.05)$ high xylanase yield of $10.4 \mathrm{Uml}^{-1}$ and $10.0 \mathrm{Uml}^{-1}$ using $\mathrm{NH}_{4} \mathrm{Cl}$ and $\left(\mathrm{NH}_{4}\right)_{2} \mathrm{SO}_{4}$ as nitrogen source respectively. Trichoderma sp $\mathrm{Fd} 7$ produced $9.7 \mathrm{Uml}^{-1}$ of xylanase enzyme by utilizing $\left(\mathrm{NH}_{4}\right)_{2} \mathrm{SO}_{4}$ and urea as source of nitrogen. The enzyme activity was completely repressed by $\mathrm{NH}_{4} \mathrm{NO}_{3}$ when used as nitrogen source for xylanase production by Aspergillus ustus Fb2 (Figure 1).

The optimal temperature for xylanase production by all the test organisms was $40{ }^{\circ} \mathrm{C}$, except for $T$. viride $\mathrm{Fd} 18$ whose optimum temperature for xylanase synthesis was $30{ }^{\circ} \mathrm{C}$. The least xylanase activity was $0.3 \mathrm{Uml}^{-1}$ at 55 ${ }^{\circ} \mathrm{C}$ produced by A. ustus Fb2. Trichoderma $\mathrm{sp}$ $\mathrm{Fd} 7$ produced significantly higher $(\mathrm{p} \leq 0.05)$ $\left(8.8 \mathrm{Uml}^{-1}\right.$ ) xylanase at $40{ }^{\circ} \mathrm{C}$ (Figure 2 ).

The least xylanase activity of $0.9 \mathrm{U} \mathrm{ml}^{-1}$ was obtained with Trichoderma sp $\mathrm{Fd} 4$ at an initial medium $\mathrm{pH}$ of 8.0 and 9.0. The $\mathrm{pH} 9$ was the initial $\mathrm{pH}$ at which the lowest activity for xylanase was obtained by all the organisms. The best initial $\mathrm{pH}$ for xylanase production was pH 5.0 (10.4 $\mathrm{Uml}^{-1}$ ) for $T$. viride $\mathrm{Fd} 18$. This figure was significantly different from the xylanase activities at other $\mathrm{pH}$ values. High xylanase activities were also produced by 
Trichoderma $\mathrm{sp} \mathrm{Fd} 4$ at $\mathrm{pH} 4.5\left(10 \mathrm{Uml}^{-1}\right), \mathrm{pH}$ 5 and $6\left(9.5 \mathrm{Uml}^{-1}\right)$; and by $T$. viride $\mathrm{Fd} 18$ at pH 6.0 (10 $\left.\mathrm{Uml}^{-1}\right)$ (Figure 3).

Xylanase was best produced on day 7 of incubation by all the fungal isolates. The amount of enzyme produced increased up to the maximum level and then decreased. $T$. viride $\mathrm{Fd} 18$, with an activity of $9.2 \mathrm{Uml}^{-1}$, had the highest xylanase activity that was significantly different $(\mathrm{p} \leq 0.05)$ from the others. The xylanase activity of $T$. viride Fd18 is about 2.5 fold that produced by $A$. ustus $\mathrm{Fb} 2$ (3.95 $\mathrm{Uml}^{-1}$ ) (Figure 4).

All the fungal isolates showed a general trend of increased production of xylanase in the presence of $\mathrm{NaCl}$ and $\mathrm{KCl}$ in the basal medium. The presence of $\mathrm{CuCl}_{2}$, $\mathrm{ZnCl}_{2}$ and $\mathrm{AlCl}_{3}$ in the basal medium decreased the production of xylanase by the five fungal isolates (Table 4).

The effect of spore inoculum size on xylanase production is shown in Figure 5 . Higher inoculum concentration of $1 \times 10^{6}$ spore's $\mathrm{ml}^{-1}$ enabled the maximum enzyme production to be reached, giving a maximum xylanase activity (16.7 $\mathrm{Uml}^{-1}, T$. viride $\mathrm{Fd18}$ ) in seven days. Higher inoculum size require shorter time to attain maximum enzyme yields, e.g., T. viride Fd18 spore concentration of $1 \times$ $10^{6}$ spores $\mathrm{ml}^{-1}$ gave a significantly higher xylanase yield of $15.2 \mathrm{Uml}^{-1}$ in 5 days compared to $6.5 \mathrm{Uml}^{-1}$ obtained in seven days using $1 \times 10^{4}$ spores $\mathrm{ml}^{-1}$. The same pattern was recorded by the other fungal isolates in the production of the enzyme.

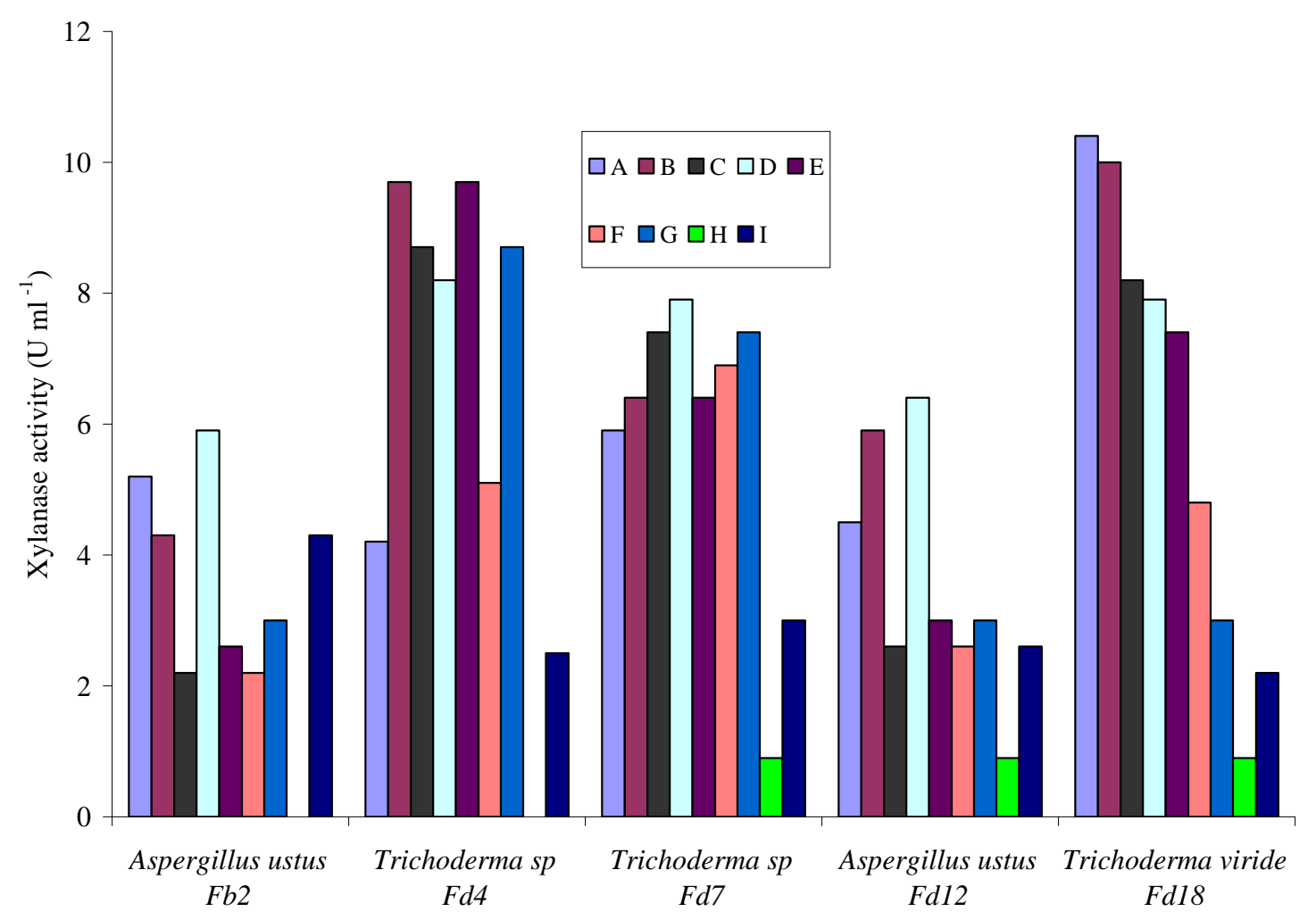

Figure 1: Effect of nitrogen sources on xylanase synthesis by selected fungal isolates. Data are presented as means of 2 replicates, having standard deviation within the range $0-8 \% . \mathrm{A}=\mathrm{NH}_{4} \mathrm{Cl}, \mathrm{B}=\left(\mathrm{NH}_{4}\right)_{2} \mathrm{SO}_{4}$, $\mathrm{C}=\mathrm{NaNO}_{3}, \mathrm{D}=\mathrm{NH}_{4} \mathrm{H}_{2} \mathrm{PO}_{4}, \mathrm{E}=\mathrm{Urea}, \mathrm{F}=\mathrm{KNO}_{3}, \mathrm{G}=\left(\mathrm{NH}_{2}\right)_{2} \mathrm{HPO}_{4}, \mathrm{H}=\mathrm{NH}_{4} \mathrm{NO}_{3}, \mathrm{I}=$ Peptone. 


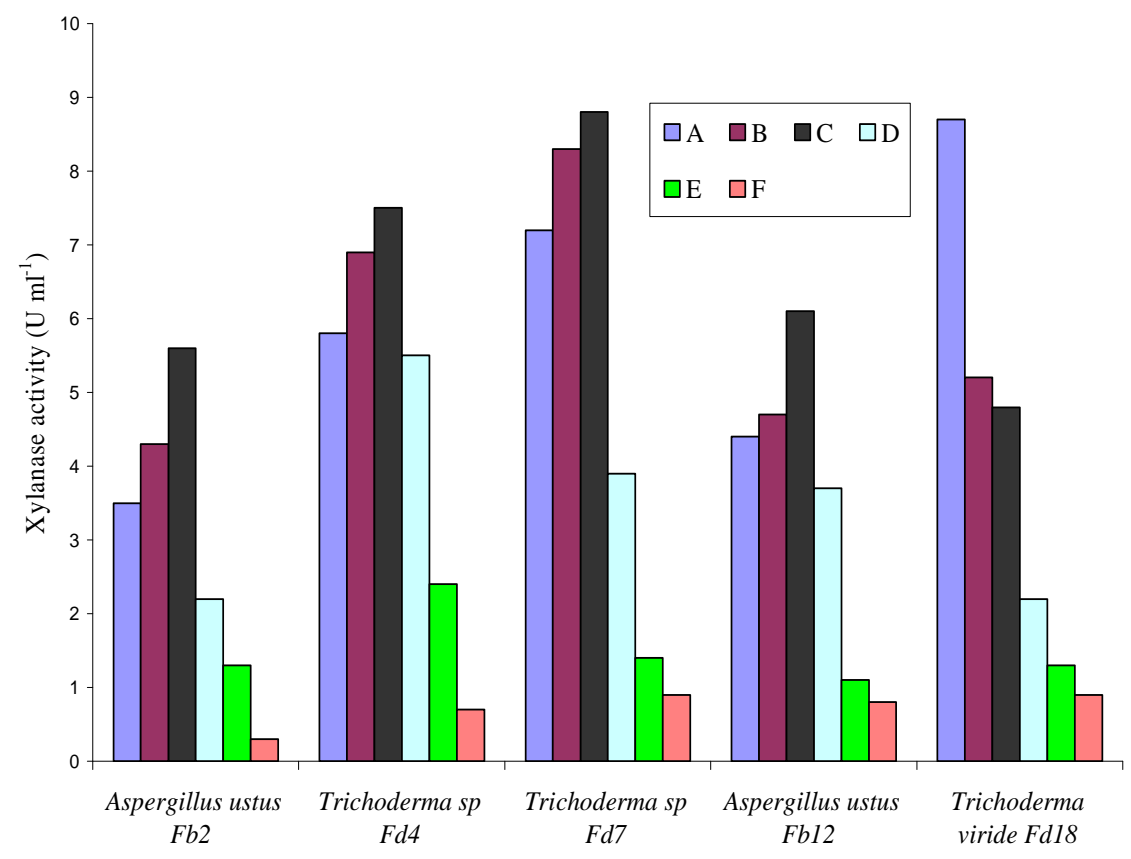

Figure 2: Effect of incubation temperatures on xylanase synthesis by fungal isolates. Data are presented as means of 2 replicates, having standard deviation within the range $0-8 \% . \mathrm{A}=30^{\circ} \mathrm{C}, \mathrm{B}=35^{\circ} \mathrm{C}, \mathrm{C}=40{ }^{\circ} \mathrm{C}, \mathrm{D}=45^{\circ} \mathrm{C}, \mathrm{E}=$ $50{ }^{\circ} \mathrm{C}, \mathrm{F}=55^{\circ} \mathrm{C}$.

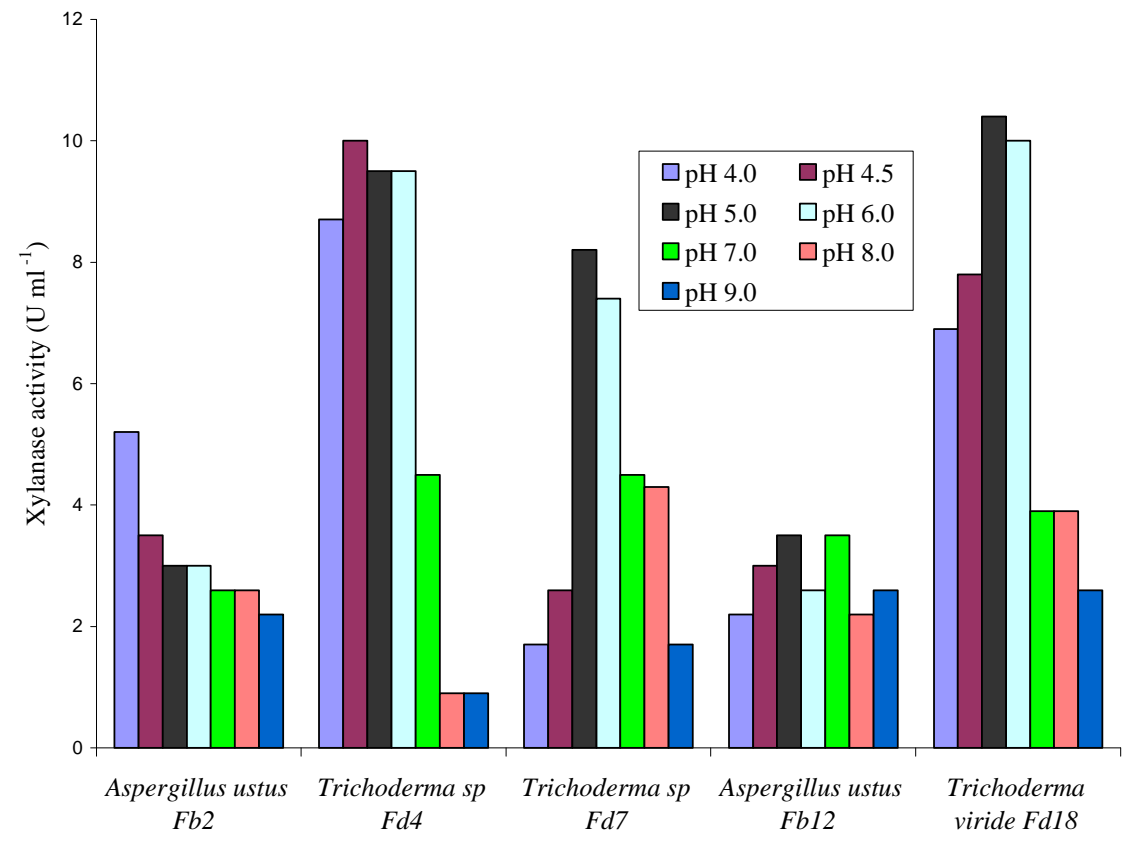

Figure 3: Effect of $\mathrm{pH}$ on xylanase synthesis by fungal isolates. Data are presented as means of 2 replicates, having standard deviation within the range $0-8 \%$. 


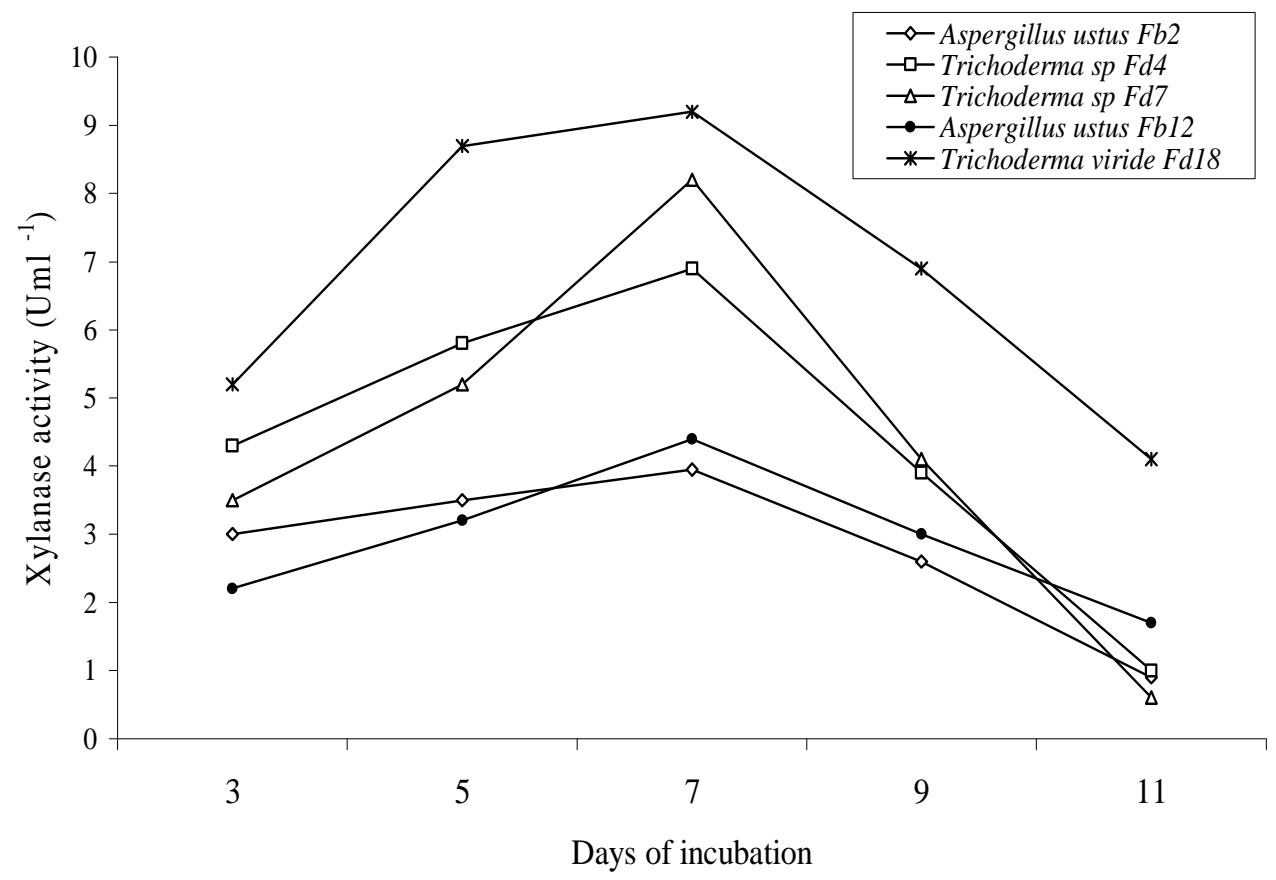

Figure 4: Effect of number of days of incubation at $30^{\circ} \mathrm{C}$ on xylanase synthesis by fungal isolates. Data are presented as means of 2 replicates, having standard deviation within the range $0-8 \%$.

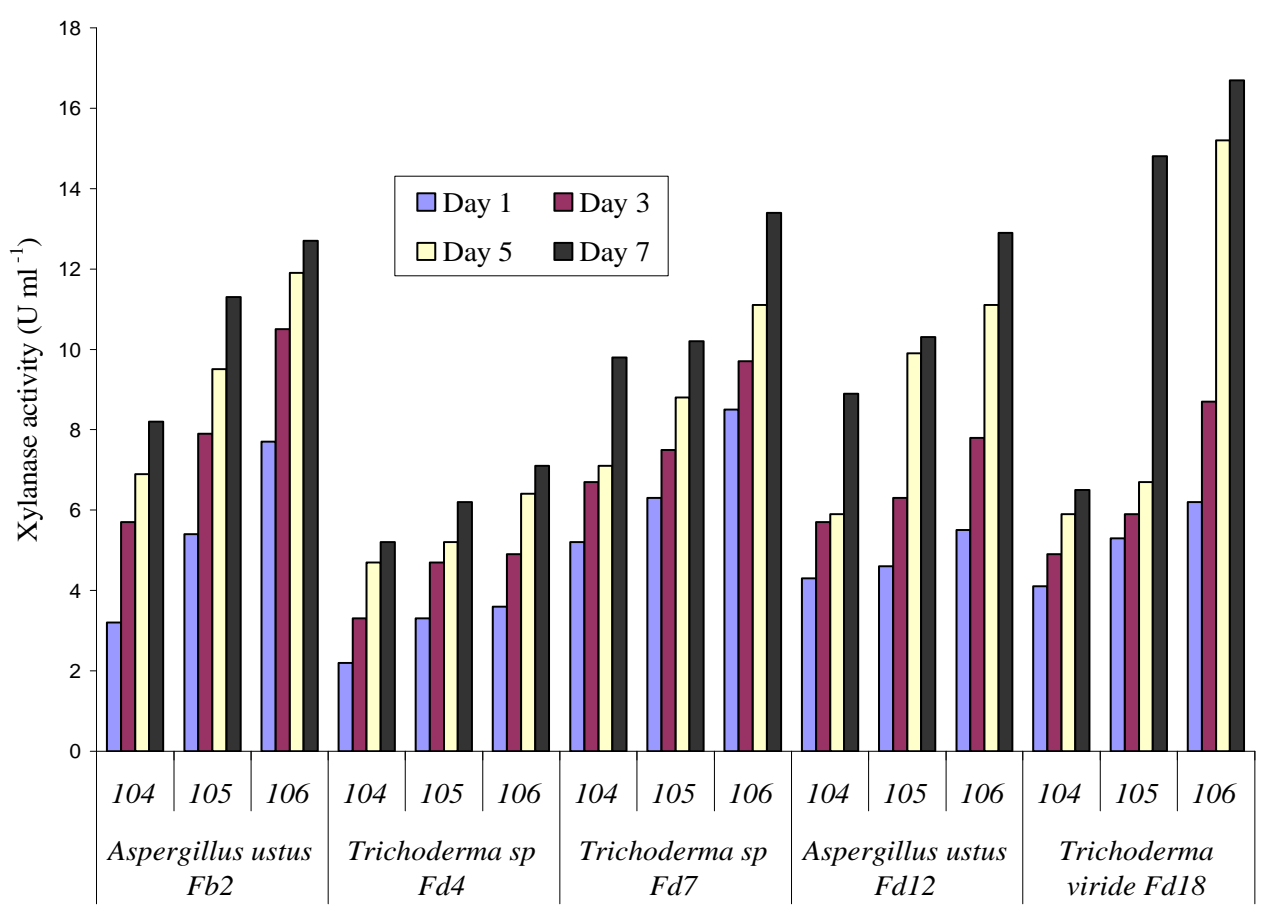

Figure 5: Effect of spore inoculum size on xylanase synthesis by fungal isolates. Data are presented as

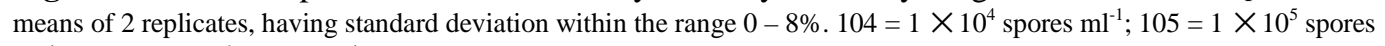
$\mathrm{ml}^{-1} ; 106=1 \times 10^{6}$ spores $\mathrm{ml}^{-1}$. 
M. I. JA'AFARU and A. A ONILUDE / Int. J. Biol. Chem. Sci. 8(1): 324-339, 2014

Table 1: Effect of different concentrations of carbohydrates on the production of xylanase enzymes by fungal isolates.

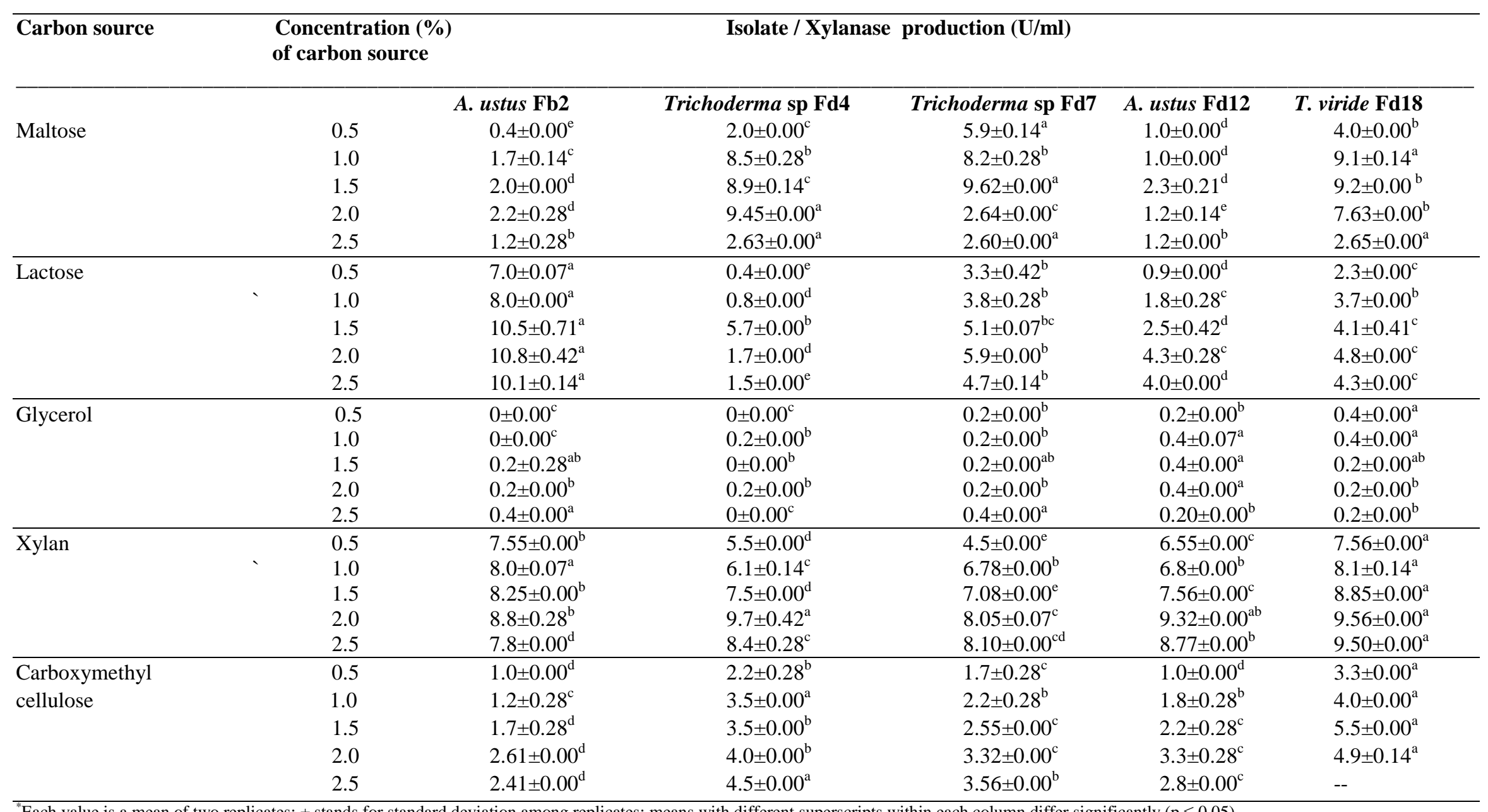

"Each value is a mean of two replicates; \pm stands for standard deviation among replicates; means with different superscripts within each column differ significantly (p $\leq 0.05$ ). 
M. I. JA'AFARU and A. A ONILUDE / Int. J. Biol. Chem. Sci. 8(1): 324-339, 2014

Table 2: Effect of different lignocellulosic substrates on xylanase production by the fungal isolates.

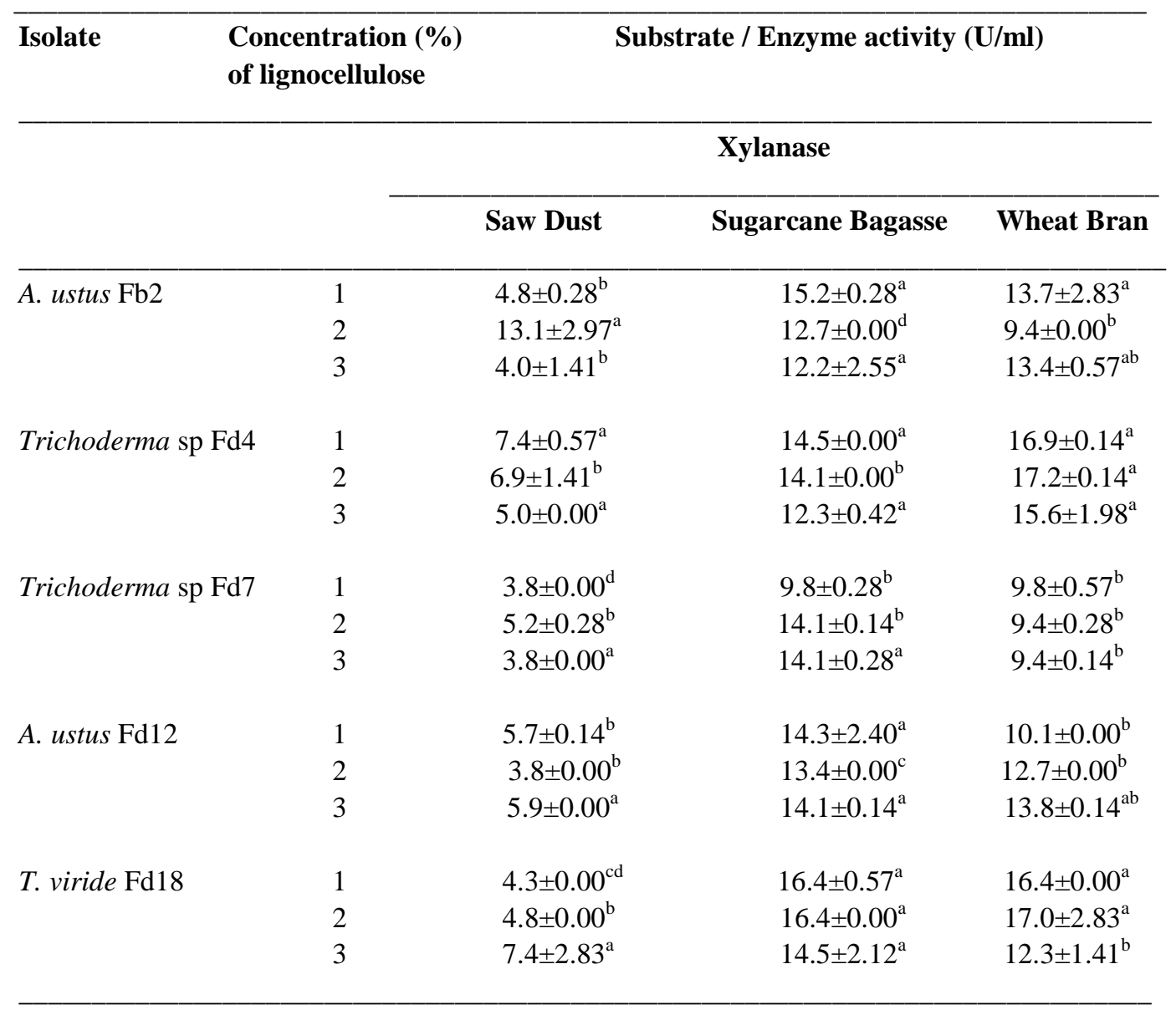

SD - Saw dust ; SB - Sugarcane bagasse; $\quad$ WB - Wheat bran ; "Each value is a mean of two replicates,

\pm stands for standard deviation among replicates; means with different superscripts within each column differ significantly $(\mathrm{p} \leq 0.05)$. 
M. I. JA'AFARU and A. A ONILUDE /Int. J. Biol. Chem. Sci. 8(1): 324-339, 2014

Table 3: Comparison of production of xylanase, filter paper activity (FPA) and cellulase on various lignocelluloses in solid state and submerged fermentation.

\begin{tabular}{|c|c|c|c|c|c|c|c|}
\hline \multirow{2}{*}{\multicolumn{2}{|c|}{ Isolate / Substrate }} & \multirow{2}{*}{\multicolumn{2}{|c|}{ Xylanase }} & \multicolumn{2}{|c|}{ FPA } & \multirow{2}{*}{\multicolumn{2}{|c|}{ Cellulase }} \\
\hline & & & & & & & \\
\hline \multicolumn{8}{|l|}{ Aspergillus } \\
\hline \multirow[t]{3}{*}{ ustus $\mathrm{Fb} 2$} & Wheat bran & ${ }^{*} 11.8 \pm 1.13^{\mathrm{c}}$ & $13.2 \pm 0.28^{\mathrm{b}}$ & $4.8 \pm 0.57^{\mathrm{b}}$ & $5.4 \pm 0.00^{\mathrm{b}}$ & $14.8 \pm 0.42^{\mathrm{a}}$ & $16.7 \pm 0.99^{\mathrm{a}}$ \\
\hline & Sugarcane bagasse & $14.5 \pm 0.71^{\mathrm{a}}$ & $14.8 \pm 0.42^{\mathrm{ab}}$ & $6.2 \pm 0.28^{\mathrm{a}}$ & $3.6 \pm 0.14^{\mathrm{a}}$ & $10.5 \pm 0.71^{\mathrm{b}}$ & $12.2 \pm 0.28^{\mathrm{a}}$ \\
\hline & Saw dust & $7.9 \pm 0.57^{\mathrm{a}}$ & $5.0 \pm 0.00^{\mathrm{ab}}$ & $3.0 \pm 0.00^{\mathrm{b}}$ & $3.2 \pm 0.28^{\mathrm{a}}$ & $10.1 \pm 2.83^{\mathrm{a}}$ & $8.9 \pm 2.83^{\mathrm{a}}$ \\
\hline \multicolumn{8}{|l|}{ Trichoderma } \\
\hline \multirow[t]{3}{*}{ sp Fd4 } & Wheat bran & $15.2 \pm 0.00^{\mathrm{a}}$ & $16.5 \pm 0.71^{\mathrm{a}}$ & $7.7 \pm 0.00^{\mathrm{a}}$ & $8.0 \pm 1.41^{\mathrm{a}}$ & $12.8 \pm 0.42^{\mathrm{b}}$ & $14.3 \pm 0.00^{\mathrm{b}}$ \\
\hline & Sugarcane bagasse & $10.1 \pm 0.14^{\mathrm{b}}$ & $13.0 \pm 0.71^{\mathrm{bc}}$ & $3.5 \pm 0.71^{\mathrm{bc}}$ & $4.1 \pm 0.00^{\mathrm{b}}$ & $8.7 \pm 0.28^{\mathrm{cd}}$ & $11.0 \pm 1.41^{\mathrm{b}}$ \\
\hline & Saw dust & $6.3 \pm 0.42^{\mathrm{ab}}$ & $6.0 \pm 1.41^{\mathrm{a}}$ & $1.8 \pm 0.57^{\mathrm{c}}$ & $2.1 \pm 0.00^{b}$ & $5.3 \pm 0.28$ & $6.8 \pm 0.28^{\mathrm{ab}}$ \\
\hline \multicolumn{8}{|l|}{ Trichoderma } \\
\hline \multirow[t]{3}{*}{ sp Fd7 } & Wheat bran & $8.5 \pm 1.41^{\mathrm{d}}$ & $8.0 \pm 0.00^{\mathrm{d}}$ & $4.3 \pm 0.42^{\mathrm{b}}$ & $9.5 \pm 0.42^{\mathrm{b}}$ & $9.5 \pm 0.71^{\mathrm{c}}$ & $12.5 \pm 0.28^{\mathrm{c}}$ \\
\hline & Sugarcane bagasse & $7.1 \pm 0.14^{\mathrm{c}}$ & $9.2 \pm 0.28^{\mathrm{d}}$ & $5.0 \pm 1.41^{\mathrm{ab}}$ & $6.2 \pm 0.28^{\mathrm{b}}$ & $9.7 \pm 0.28^{\mathrm{cb}}$ & $11.2 \pm 0.28^{\mathrm{b}}$ \\
\hline & Saw dust & $4.9 \pm 0.00^{\mathrm{bc}}$ & $4.1 \pm 0.14^{\mathrm{b}}$ & $5.7 \pm 0.28^{\mathrm{a}}$ & $2.0 \pm 0.00^{\mathrm{b}}$ & $2.1 \pm 0.00^{\mathrm{e}}$ & $4.5 \pm 1.41^{\mathrm{bc}}$ \\
\hline \multicolumn{8}{|l|}{ Aspergillus } \\
\hline \multirow[t]{3}{*}{ ustus Fd12 } & Wheat bran & $10.5 \pm 0.71^{\mathrm{b}}$ & $13.3 \pm 0.42^{\mathrm{c}}$ & $4.5 \pm 0.71^{\mathrm{b}}$ & $3.5 \pm 0.71^{\mathrm{bc}}$ & $11.7 \pm 0.28^{\mathrm{a}}$ & $15.2 \pm 1.41^{\mathrm{c}}$ \\
\hline & Sugarcane bagasse & $9.4 \pm 0.57^{\mathrm{b}}$ & $11.5 \pm 0.71^{\mathrm{c}}$ & $4.2 \pm 0.28^{\mathrm{abc}}$ & $2.8 \pm 0.28^{\mathrm{b}}$ & $12.7 \pm 1.41^{\mathrm{a}}$ & $10.6 \pm 0.14^{\mathrm{b}}$ \\
\hline & Saw dust & $3.9 \pm 0.57^{\mathrm{c}}$ & $5.1 \pm 0.14^{\mathrm{ab}}$ & $2.2 \pm 0.28^{c}$ & $1.8 \pm 0.14^{\mathrm{b}}$ & $3.5 \pm 1.41^{\mathrm{d}}$ & $2.7 \pm 0.00^{c}$ \\
\hline \multicolumn{8}{|l|}{ Trichoderma } \\
\hline \multirow{2}{*}{ viride $\mathrm{Fd} 18$} & Sugarcane bagasse & $14.3 \pm 0.42^{\mathrm{a}}$ & $15.9 \pm 0.42^{\mathrm{a}}$ & $2.6 \pm 0.14^{c}$ & $3.8 \pm 0.14^{\mathrm{b}}$ & $8.3 \pm 0.00^{\mathrm{d}}$ & $12.7 \pm 0.99^{a}$ \\
\hline & Saw dust & $6.4 \pm 0.57^{\mathrm{c}}$ & $4.6 \pm 0.42^{\mathrm{b}}$ & $0.85 \pm 0.07^{\mathrm{d}}$ & $1.8 \pm 0.00^{\mathrm{b}}$ & $4.2 \pm 0.28^{\mathrm{b}}$ & $3.8 \pm 1.13^{\mathrm{c}}$ \\
\hline
\end{tabular}

SSF - Solid state fermentation; SmF - Submerged fermentation; "Each value is a mean of two replicates; \pm stands for standard deviation among replicates; means with different superscripts within each column differ significantly $(\mathrm{p} \leq 0.05)$. 
M. I. JA'AFARU and A. A ONILUDE / Int. J. Biol. Chem. Sci. 8(1): 324-339, 2014

Table 4: Effect of different mineral salts on xylanase synthesis by fungal isolates.

\begin{tabular}{|c|c|c|c|c|c|}
\hline \multirow[t]{2}{*}{ Mineral salts } & \multicolumn{5}{|c|}{ Fungal isolates / Xylanase activity $\left(\mathrm{U} \mathrm{ml}^{-1}\right)$} \\
\hline & A. ustus Fb4 & Trichoderma sp Fd4 & Trichoderma sp Fd7 & A. ustus Fd12 & T. viride Fd18 \\
\hline Control & $9.3 \pm 2.83^{\mathrm{a}}$ & $9.5 \pm 0.71^{\mathrm{a}}$ & $8.1 \pm 0.00^{\mathrm{a}}$ & $9.3 \pm 0.42^{\mathrm{a}}$ & $9.5 \pm 1.41^{\mathrm{a}}$ \\
\hline $\mathrm{CaCl}_{2}$ & $10.6 \pm 0.85^{\mathrm{a}}$ & $8.2 \pm 0.28^{b}$ & $6.1 \pm 0.14^{\mathrm{b}}$ & $9.7 \pm 0.00^{\mathrm{a}}$ & $9.9 \pm 0.00^{\mathrm{a}}$ \\
\hline $\mathrm{FeSO}_{4}$ & $10.3 \pm 0.00^{\mathrm{a}}$ & $9.4 \pm 0.57^{\mathrm{ab}}$ & $8.0 \pm 1.41^{\mathrm{a}}$ & $9.3 \pm 4.24^{\mathrm{a}}$ & $9.4 \pm 2.83^{\mathrm{a}}$ \\
\hline $\mathrm{MgSO}_{4}$ & $10.4 \pm 0.00^{\mathrm{a}}$ & $9.6 \pm 0.42^{\mathrm{a}}$ & $8.1 \pm 0.14^{\mathrm{a}}$ & $9.5 \pm 0.00^{\mathrm{a}}$ & $9.9 \pm 0.57^{\mathrm{a}}$ \\
\hline $\mathrm{NaCl}$ & $10.9 \pm 0.57^{\mathrm{a}}$ & $10.1 \pm 0.00^{\mathrm{a}}$ & $9.2 \pm 0.28^{\mathrm{a}}$ & $9.8 \pm 1.70^{\mathrm{a}}$ & $10.7 \pm 0.00^{\mathrm{a}}$ \\
\hline $\mathrm{KCl}$ & $11.7 \pm 0.99^{\mathrm{a}}$ & $9.9 \pm 0.57^{\mathrm{a}}$ & $9.3 \pm 0.42^{\mathrm{a}}$ & $10.2 \pm 0.28^{\mathrm{a}}$ & $10.5 \pm 0.71^{\mathrm{a}}$ \\
\hline $\mathrm{CuCl}_{2}$ & $3.9 \pm 0.00^{b}$ & $4.7 \pm 0.99^{\mathrm{d}}$ & $2.9 \pm 0.00^{\mathrm{c}}$ & $1.8 \pm 0.00^{b}$ & $2.7 \pm 042^{b}$ \\
\hline $\mathrm{ZnCl}_{2}$ & $3.3 \pm 1.41^{b}$ & $4.1 \pm 0.00^{\mathrm{d}}$ & $2.7 \pm 0.57^{\mathrm{c}}$ & $1.2 \pm 0.00^{\mathrm{b}}$ & $2.0 \pm 0.00^{\mathrm{b}}$ \\
\hline $\mathrm{AlCl}_{3}$ & $5.7 \pm 0.00^{\mathrm{b}}$ & $6.3 \pm 0.42^{\mathrm{c}}$ & $3.3 \pm 0.00^{\mathrm{c}}$ & $2.8 \pm 0.57^{\mathrm{b}}$ & $3.5 \pm 0.71^{\mathrm{b}}$ \\
\hline
\end{tabular}

Each value is a mean of two replicates; \pm stands for standard deviation among replicates; means with different superscripts

within each column differ significantly $(\mathrm{p} \leq 0.05)$. 


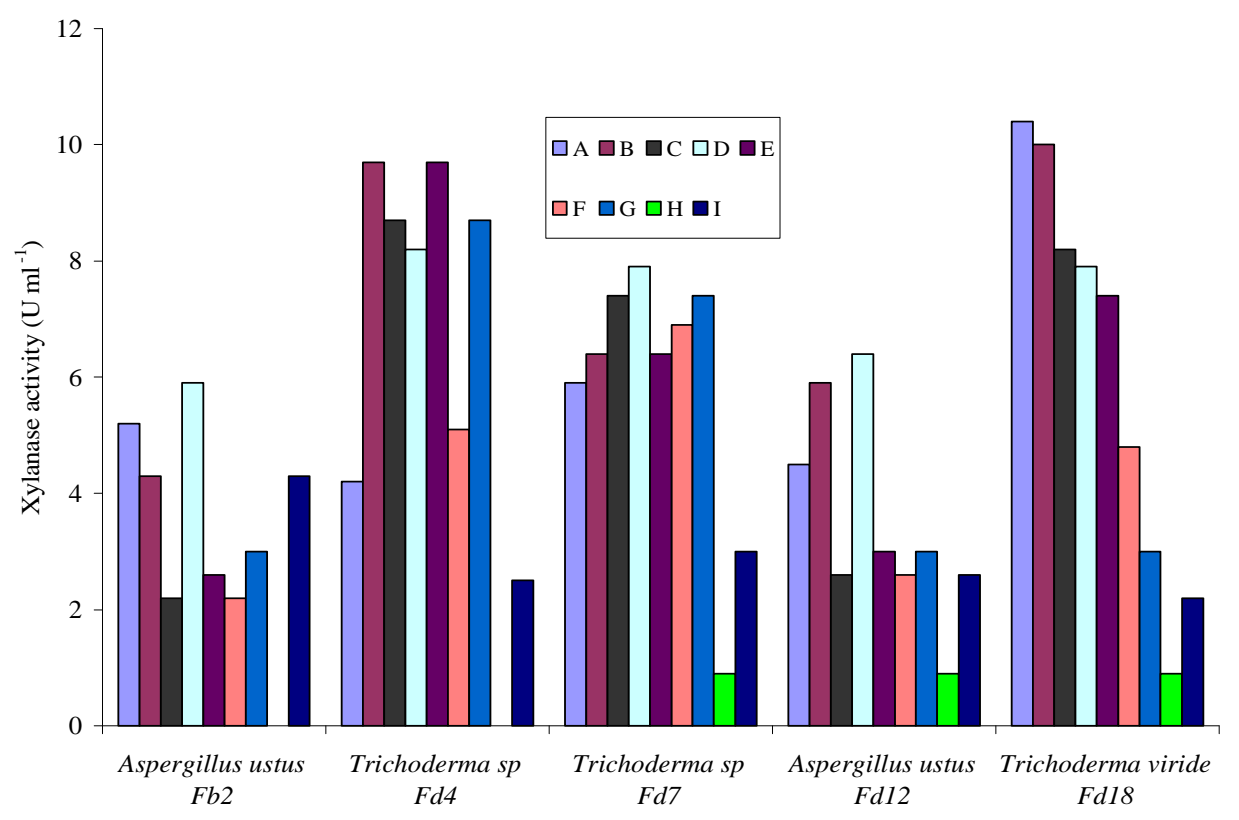

Figure 1: Effect of nitrogen sources on xylanase synthesis by selected fungal isolates. Data are presented as means of 2 replicates, having standard deviation within the range $0-8 \%$. A $=\mathrm{NH}_{4} \mathrm{Cl}$, B $=\left(\mathrm{NH}_{4}\right)_{2} \mathrm{SO}_{4}$, $\mathrm{C}=\mathrm{NaNO}_{3}, \mathrm{D}=\mathrm{NH}_{4} \mathrm{H}_{2} \mathrm{PO}_{4}, \mathrm{E}=\mathrm{Urea}, \mathrm{F}=\mathrm{KNO}_{3}, \mathrm{G}=\left(\mathrm{NH}_{2}\right)_{2} \mathrm{HPO}_{4}, \mathrm{H}=\mathrm{NH}_{4} \mathrm{NO}_{3}, \mathrm{I}=$ Peptone.

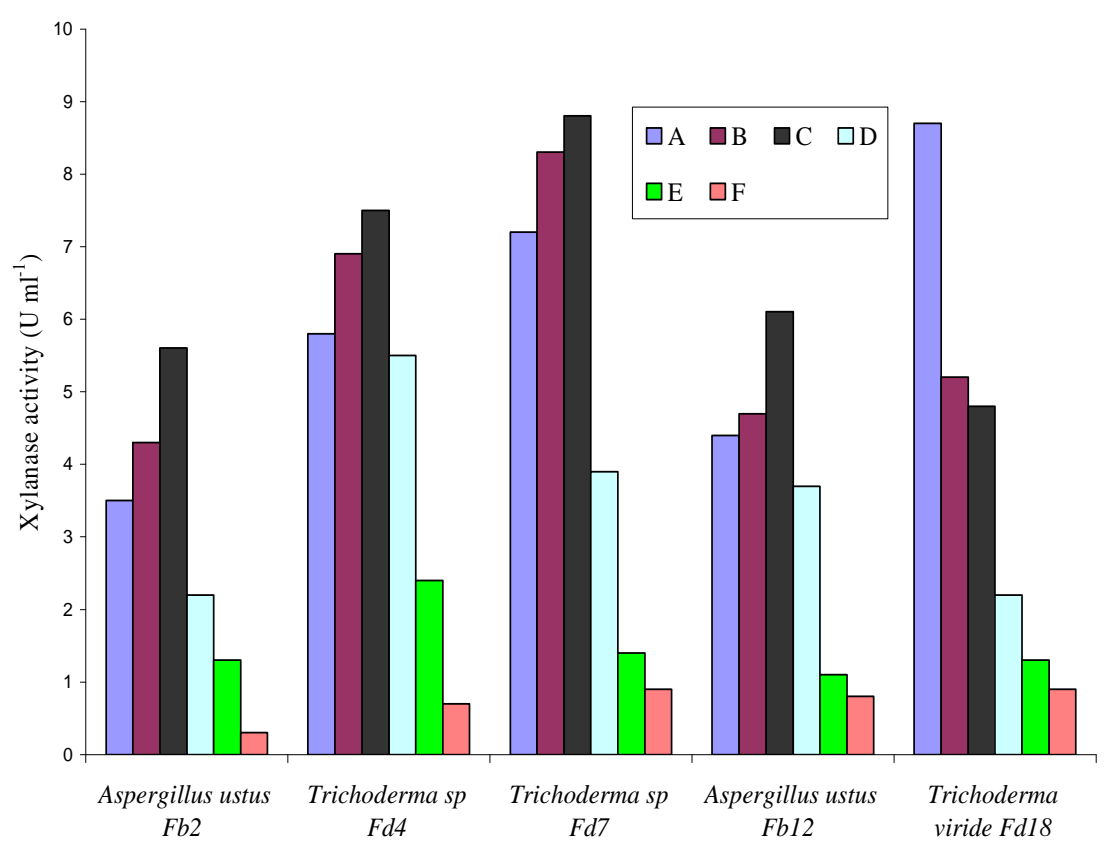

Figure 2: Effect of incubation temperatures on xylanase synthesis by fungal isolates. Data are presented as means of 2 replicates, having standard deviation within the range $0-8 \%$. $\mathrm{A}=30^{\circ} \mathrm{C}, \mathrm{B}=35^{\circ} \mathrm{C}, \mathrm{C}=40^{\circ} \mathrm{C}, \mathrm{D}=45^{\circ} \mathrm{C}, \mathrm{E}=$ $50{ }^{\circ} \mathrm{C}, \mathrm{F}=55^{\circ} \mathrm{C}$. 


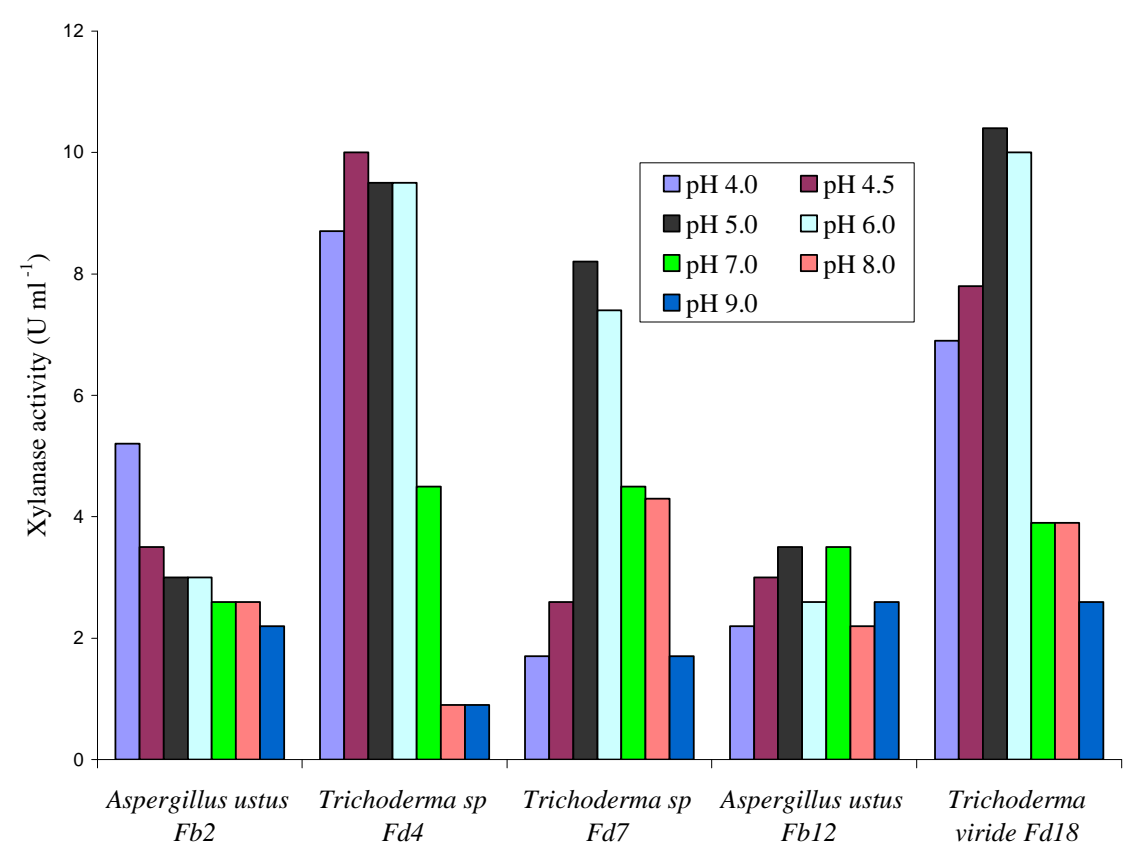

Figure 3: Effect of $\mathrm{pH}$ on xylanase synthesis by fungal isolates. Data are presented as means of 2 replicates, having standard deviation within the range $0-8 \%$.

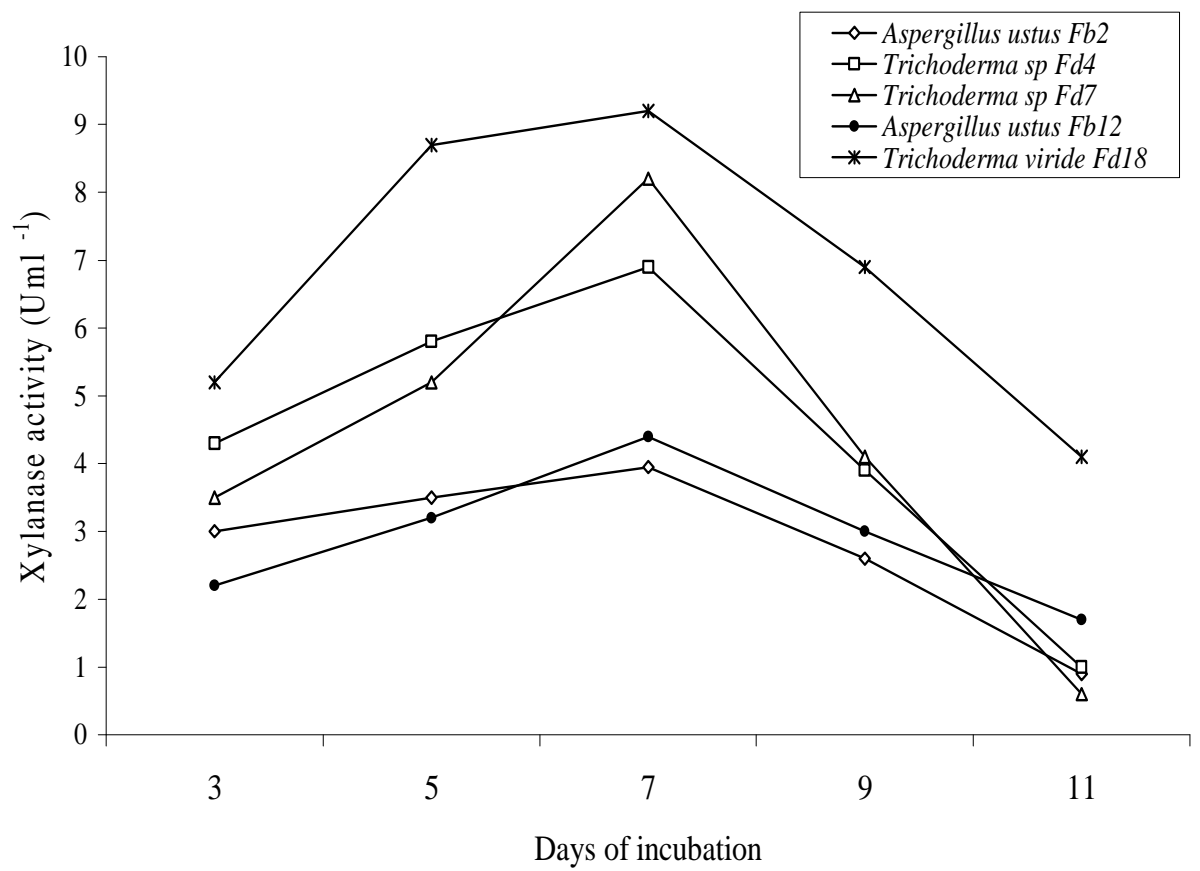

Figure 4: Effect of number of days of incubation at $30^{\circ} \mathrm{C}$ on xylanase synthesis by fungal isolates. Data are presented as means of 2 replicates, having standard deviation within the range $0-8 \%$. 


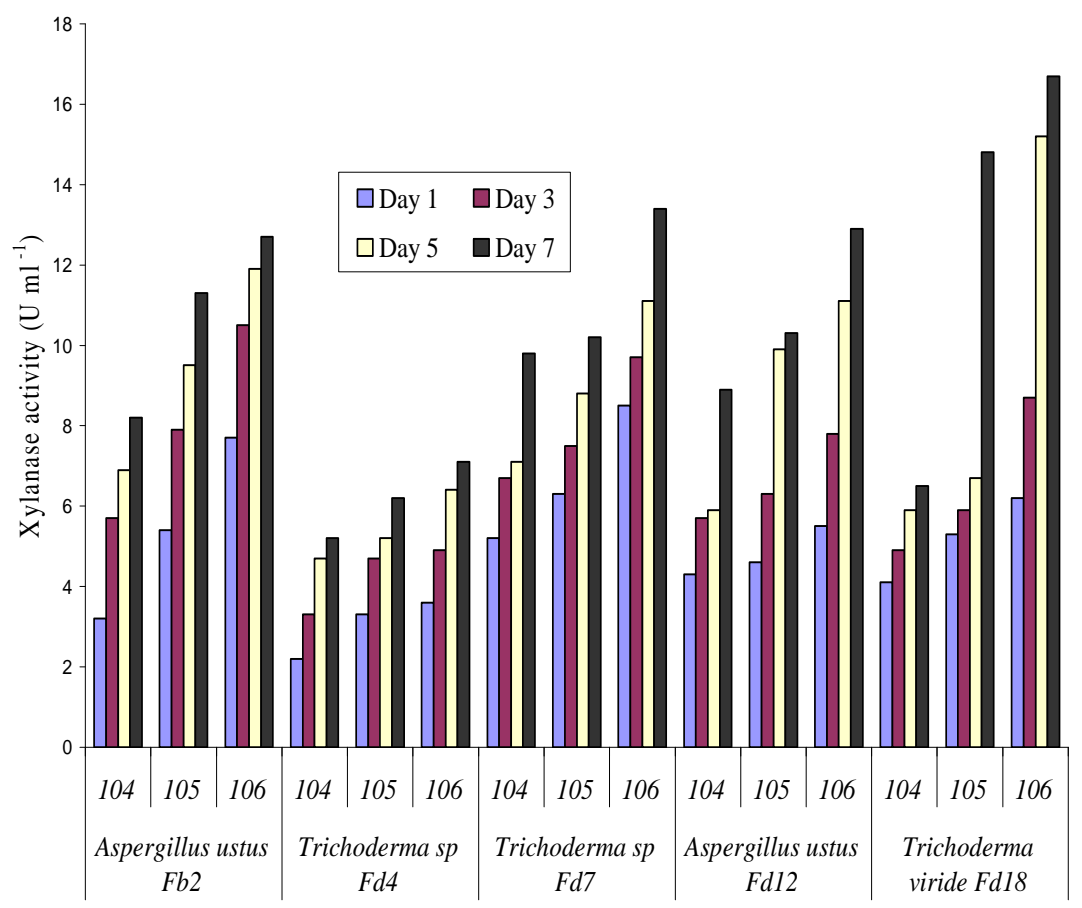

Figure 5: Effect of spore inoculum size on xylanase synthesis by fungal isolates. Data are presented as means of 2 replicates, having standard deviation within the range $0-8 \% .104=1 \times 10^{4}$ spores $\mathrm{ml}^{-1} ; 105=1 \times 10^{5}$ spores $\mathrm{ml}^{-1} ; 106=1 \times 10^{6}$ spores $\mathrm{ml}^{-1}$.

\section{DISCUSSION}

Production of microbial enzymes is dependent upon various nutritional and cultural parameters such as $\mathrm{pH}$, temperature, carbon and nitrogen sources. These parameters were studied in order to optimize the production of lignocellulolytic enzymes by selected fungal isolates.

Oat-spelt xylan $(2 \%)$ was the carbon source of choice for xylanase synthesis by Trichoderma sp. Fd4, A. ustus Fd12 and T. viride Fd18 (Table 1). Xylan or a xylancontaining carbon source is necessary for a satisfactory production of xylanase by many microorganisms, not only because it is the main carbon source, but probably also because its hydrolysis products act as inducers (Ding et al., 2004). Different carbohydrates were studied for xylanase production by Trichoderma with xylan being reported to induce high levels of xylanase (Gaanappriya et al., 2011). These findings are in agreement with the results in this work. The decrease in enzyme activity in the presence of high substrate concentration may be attributed to a partial adsorption of the enzymes to the substrate and to a strong decrease in $\mathrm{pH}$ that becomes inhibitory for the growth of the fungus and induction of the enzyme synthesis (Szczodrak, 1988).

The production of low levels of enzymes in the presence of glucose, glycerol or other carbon sources related to glycolytic mechanism may be due to catabolite repression, a regulatory mechanism known to control enzyme production in bacteria and fungi. In this case, the end product of lignocellulose hydrolysis may interact with a particular gene at the transcription level and represses enzyme synthesis (Lockington et al., 2002; Rajoka, 2004; Moussa and Tharwat, 2007).

When agro-residues - saw dust, sugarcane bagasse and wheat bran - were supplemented as sole carbon sources for xylanase production, lignocellulosic substrates 
were observed to produce higher level of xylanase compared to the soluble sugars. Wheat bran was the best lignocellulosic substrate for the synthesis of xylanase by the fungal strains. Wheat bran was the substrate of choice by $T$. viride $\mathrm{Fd} 18$ in producing highest levels of xylanase $\left(17.0 \mathrm{Uml}^{-1}\right)$. Saw dust was a poor inducer of enzymes in this study. This result is in agreement with the findings of Xu et al. (2005) and Muthezilan et al. (2007), who reported the production enzymes using wheat bran as substrate. Wheat bran not only contains many nutrients needed for cell growth including various amino acids, but also serves as an inducer for xylanase production due to its high xylan content (30\%). Wheat bran is also an abundant and cheap agricultural residue which remains loose and well aerated in mass, even in moist conditions (Xu et al., 2005).

The nitrogen source used in a production medium is one of the major factors affecting enzyme production and level (Moussa and Tharwat, 2007). In this study, $\mathrm{NH}_{4} \mathrm{NO}_{3}$ and urea were found to be poor sources of nitrogen for induction of xylanase activity. This is in agreement with the studies of Lieckfeldt and others (2000) who reported nitrate and urea as being not suitable for Trichoderma reesei cultivations. Ammonium compounds are reported to be the most favourable nitrogen compounds for protein and enzyme synthesis (Muthezhilan et al., 2007).

In this work, Xylanase production, except by $T$. viride Fd18, was optimal at 40 ${ }^{\circ} \mathrm{C}$. The optimum temperature of $30{ }^{\circ} \mathrm{C}$ for xylanase production by $T$. viride $\mathrm{fd} 18$ is similar to other reported results that established the temperature range for xylanase production as being between $20{ }^{\circ} \mathrm{C}$ and $30{ }^{\circ} \mathrm{C}$ (Haq et al., 2004; Ikram-ul-Haq and Khan, 2006).

This study shows that any change, either increase or decrease in temperature resulted in the gradual decrease in enzyme production. According to Rahman et al. (2003) and Yuan et al. (2005), observed decreases in enzyme production at very low or high temperatures results from the inhibition of fungal growth at these temperatures, leading to a decrease in enzyme synthesis. High temperatures alter the cell membrane composition raising the maintenance energy requirement for cellular growth due to thermal denaturation of enzymes of the metabolic pathway (Ikram-ul-Haq and Khan, 2006). At lower temperature, the transport of substrates across the cells is suppressed and lower yield of products are attained (Rajoka et al., 1998).

High xylanase (Figure 2) values were obtained between $\mathrm{pH} 4.0$ and 6.0. Ahmed et al. (2003) and Pang et al. (2006) reported pH 5.5 as the optimum for xylanase and cellulase production by Aspergillus niger MSK-7, Trichoderma viride MSK-10 and Trichoderma harzianum. According to Subramaniyan and Prema (2002) a pH of around 5.0, has in general, been the optimum for xylanase production by fungi and enzyme is normally stable at $\mathrm{pH} 2.0$ to 9.0. The poor production of enzymes at high $\mathrm{pH}$ values might be due to the fact that alkaline $\mathrm{pH}$ has inhibitory effect on the growth of the fungi and enzyme production. The initial $\mathrm{pH}$ influences the transport of small amounts of enzymes across the cell membrane (Bakri et al., 2008).

All enzyme activities increased step wise and reached an optimum after 7 days of incubation (Figure 4). T. viride Fd18, with an activity of $9.2 \mathrm{Uml}^{-1}$, had the highest xylanase activity. The least activity of the enzymes was recorded on day 3 of incubation. Simoes and Tauk-Tornisielo (2006) reported that xylanase activity increased up to the fifth day and dropped considerably on the $6^{\text {th }}$ day of incubation. The depression of enzyme activity after the $7^{\text {th }}$ day may be due to cumulative effect of the reducing sugars, glucose and xylose, which are known to inhibit cellulases and xylanases respectively (Ojumu et al., 2003). Hatakka (1993) also suggested that delignification produces aromatic watersoluble products which can repress the cellulolytic action of the enzyme.

On varying inoculum size, it was observed that high inocula of $1 \times 10^{6}$ spores 
$\mathrm{ml}^{-1}$ enabled maximum xylanase production in all fungal isolates. This result is similar to reports on other fungi (Pang et al., 2006). During enzyme production, the spore concentration in fungi cultivation must be high enough to colonize the substrates particles (Simoes and Tauk-Tornisielo, 2005). Studies however, have indicated that there can be a decline in this activity over a determined spore concentration. With higher inoculum size, the time taken for the inoculum to colonize the substrate will be shortened significantly with higher enzymes productivity (Pau and Omar, 2004).

In conclusion, the result obtained from the present work indicates xylanase production from new isolates of Trichoderma and Aspergillus using selective growth and nutrient conditions. This result will facilitate scale up processes for mass production. The xylanase so produced could be used in many industrial applications after detailed characterization.

\section{REFERENCES}

Ahmed S, Ain Q, Aslam N, Naeem S, Rahman S, Jamil A. 2003. Induction of xylanase and cellulase genes from Trichoderma harzianum with different carbon sources. Pak. J. Biol. Sci., 6: 1912- 1916.

Bailey MJ, Biely P, Poutanen K. 1992. Interlaboratory testing of methods for assay of xylanase activity. $J$. Biotechnol., 23: 277-270.

Bakri Y, Jawhar M, Arabi MIE. 2008. Improvement of xylanase production by Cochliobolus sativus in submerged culture. Food Technol. Biotechnol., 46: $116-118$.

Barnett HL. 1960. Illustrated genera of mperfect fungi. Burgen Publishing Co.Minnesota.

Ding CH, Jiang ZO, Li XT, Li LT, Kusakabe I. 2004. High activity xylanase production by Streptomyces olivaceoviridis E-86. World J. Microbiol. Biotechnol., 20: 7-10.
Domsch KH, Gams W, Anderson T-H. 1980. Compendium of Soil Fungi (Vol 1). Academic Press: London.

Franco PF, Ferreira HM, Ferreira-Filho EX. 2004. Production and characterization of hemicellulase activities from Trichoderma harzianum strain T4. Biotechnol. Appl. Biochem., 40: 255-259.

Gaanappriya M, Guhankumar P, Balakrishna V. 2011. Isolation of Xylan degrading enzyme from Trichoderma spp. Res. Plt. Biol., 1: 15-20

Haq I, Tasneem M, Raana K, Khan A, Mukhtar M, Javed M. 2004. Optimization of cultural conditions for the production of xylanase by chemically mutated strains of Aspergillus niger GCBCX - 20. Intern. J. Agric. Biol., 6: 1115-1118.

Hatakka AL. 1993. Pretreatment of wheat straw by white-rot fungi for enzymatic saccharification of cellulose. Eur. J. Appl. Microbiol. Biotechnol., 18: 350-357.

Ikram-ul-Haq MMJ, Khan TS. 2006. An innovative approach for hyper production of cellulolytic and hemicellulolytic enzymes by consortium of Aspergillus niger MSK-7 and Trichoderma viride MSK-10. Afr. J. Biotechnol., 5: 609-614.

Irfan M, Syed Q. 2012. Partial purification and characterization of Xylanase from Trichoderma viride produced under SSF. Intern. J. Appl. Res. Nat. Prod., 5: 7-11.

Jeya M, Thiagarajan S, Gunasekaran P. 2005. Improvement of xylanase production in solid-state fermentation by alkali tolerant Aspergillus versicolor MKU3. Lett. Appl. Microbiol., 41: 175-178.

Kulkarni N, Shendye A, Rao M. 1999. Molecular and biotechnological aspects of xylanases. FEMS Microbiol. Rev., 23: 411-456.

La Grange DC, Claeyssens IM, Pretorius IS, Van Zyl WH. 2001. Degradation of xylan to D-xylose by recombinant Saccharomyces cerevisiae co-expressing the Aspergillus niger xylosidase $(x \ln \mathrm{D})$ and the Trichoderma reesei xylanase II (xyn2) genes. Appl. Environ. Microbiol., 67: 5512- 5519 . 
Lieckfeldt E, Kullnig C, Samuels GJ, Kubicek CP. 2000. Sexually competent, sucrose and nitrate-assimilating strains of Hypocrea jecorina (Trichoderma reesei) from South American soils. Mycolog., 92: 374-380.

Lockington RA, Rodbourn L, Barnett S, Carter CJ, Kelly JM. 2002. Regulation by carbon and nitrogen sources of a family of cellulases in Aspergillus nidulans. Fungal Gen. Biol., 37: 190-196.

Mandels M, Weber J. 1969. The production of cellulases. Adv. Chem. Ser., 95: 394-414.

Moussa TAA, Tharwat NA. 2007. Optimization of cellulase and $\beta$ glucosidase induction by sugarbeet pathogen Sclerotium rolfsii. Afr. J. Biotechnol., 6: 1048-1054.

Muthezhilan R, Ashok R, Joyalakshmi S. 2007. Production and optimization of thermostable alkaline xylanase by Penicillium oxalicum in solid state fermentation. Afr. J. Microbiol. Res., 1: 20-28.

Ojumu TV, Solomon BO, Betiku E, Layokun SK, Amigun B. 2003. Cellulase production by Aspergillus flavus Linn isolate NSPR 101 fermented in sawdust, bagasse and corncob. Afr. J. Biotechnol., 2: $150-152$.

Pang PK, Ibrahim D, Poppe L, Szackacs G, Omar IC. 2006. Production of cellulolytic enzymes by a newly isolated Trichoderma sp. FETL C3-2 via solid state fermentation grown on sugar cane bagasse:palm kernel cake as substrates. Pak. J. Biol. Sci., 9: 1430-1437.

Pau HS, Omar IC. 2004. Selection and optimization of lipase production from Aspergillus flavus USM A10 via solid state fermentation (SSF) on rice husk and wood dusts as substrates. Pak. J. Biol. Sci., 7: 1249-1256.

Rahman AK, Sugitani N, Hatsu M, Takamizawa K. 2003. A role of xylanase, alpha-arabinofuranosidase, and xylosidase in xylan degradation. Can. J. Microbiol., 49: 58-64.

Rajoka MI. 2004. Influence of various fermentation variables on exo-glucanase production in Cellulomonas flavigena. Electronic J. Biotechnol., 7(3). Available at http://www.ejbiotechnology.info/ content/vol.7/ issues/full/2/. Accessed on $3^{\text {rd }}$ May, 2006.

Rajoka MI, Bashir A, Hussain MRA, Malik KA. 1998. Mutagenesis of Cellulomonas biazotea for improved production of cellulases. Folia Microbiol., 43: 15-22.

Simoes MLG, Tauk-Tornisielo SM. 2005. Optimization of xylanase biosynthesis by Aspergillus japonicus isolated from a "Caatinga" area in the Brazilian state of Bahia. Afr. J. Biotechnol., 5: 135-1141.

Subramaniyan S, Prema P. 2002. Biotechnology of microbial xylanases: enzymology, molecular biology and application. Crit. Rev. Biotechnol., 22:33-46.

Szczodrak J. 1988. Production of cellulases and xylanases by Trichoderma reesei. F522 on pretreated wheat straw. Acta Biotechnol., 6: 509-515.

Tallapragada, P, Venkatesh, K. 2011. Isolation, identification and optimization of xylanase enzyme produced by Aspergillus niger under submerged fermentation. J. Microbiol. Biotech. Res., 1: $137-147$

Xu Z-H, Bai Y-L, Xu X, Shi J-S, Tao W-Y. 2005. Production of alkali-tolerant cellulase-free xylanase by Pseudomonas sp. WLUN024 with wheat bran as the main substrate. World J. Microbiol. Biotechnol., 21: 575-581.

Yuan Q, Wang J, Zhang H, Qian Z. 2005. Effect of temperature shift on production of xylanase by Aspergillus niger. Proc. Biochem., 40: 3255-3257. 